\title{
Miranda
}

Revue pluridisciplinaire du monde anglophone /

Multidisciplinary peer-reviewed journal on the English-

speaking world

$12 \mid 2016$

Mapping gender. Old images ; new figures

\section{Ingrid H. Tague, Animal Companions: Pets and Social Change in Eighteenth-Century Britain}

Laurence Talairach-Vielmas

URL : http://journals.openedition.org/miranda/8060

DOI : 10.4000/miranda. 8060

ISSN : 2108-6559

Éditeur

Université Toulouse - Jean Jaurès

Référence électronique

Laurence Talairach-Vielmas, «Ingrid H. Taque, Animal Companions: Pets and Social Change in

Eighteenth-Century Britain », Miranda [En ligne], 12 | 2016, mis en ligne le 14 mars 2016, consulté le 16 février 2021. URL : http://journals.openedition.org/miranda/8060 ; DOI : https://doi.org/10.4000/ miranda. 8060

Ce document a été généré automatiquement le 16 février 2021.

\section{(c) $(1)$}

Miranda is licensed under a Creative Commons Attribution-NonCommercial-NoDerivatives 4.0 International License. 


\title{
Ingrid H. Tague, Animal Companions: Pets and Social Change in Eighteenth- Century Britain
}

\author{
Laurence Talairach-Vielmas
}

\section{RÉFÉRENCE}

Ingrid H. Tague, Animal Companions: Pets and Social Change in Eighteenth-Century Britain (University Park, Pennsylvania: The Pennsylvania State University Press, 2015), 298 p, ISBN 978-0-271-06588-5

1 Ingrid H. Tague's Animal Companions: Pets and Social Change in Eighteenth-Century Britain is Animalbus's fifth volume - a series which includes books such as Rachel Poliquin's The Breathless Zoo: Taxidermy and the Cultures of Longing (2012), Gorgeous Beasts: Animal Bodies in Historical Perspective (2012), edited by Joan B. Landes, Paula Young Lee and Paul Youngquist, and Animals on Display: The Creaturely in Museums, Zoos and Natural History (2013), edited by Liv Emma Thorsen, Karen A. Rader and Adam Dodd. Animal Companions explores the development of modern pet-keeping in eighteenth-century Britain, at a time when debates on the relationships between humans and animals, the issue of equality, morality or the question of animal rights were part and parcel of Georgian Britain. As Tague explains, pets blurred to some extent the distinction between humans and non humans, helping thereby conceptualize human-animal relations.

2 In Chapter 1, Tague looks at pets in the context of eighteenth-century consumer society: in eighteenth-century London, pets were more often than not living consumer goods, especially as aristocrats often craved for new exotic additions to their menageries, birds or even dogs for hunting. The market for pets benefited from the rise of consumer society just as it reflected the development of the British empire and the interest in the natural world more generally. For pets - animals kept at home - also helped (amateur) naturalists describe their behaviour or classify the beasts from far 
away lands. Using advertisings from mid-eighteenth-century papers, Tague manages to rewrite the story of how the wealthy classes (and all social classes from the 1850s) sold and bought their animals, looked after them, showing how pets increasingly stood as images of taste and education, displayed in the house alongside other (inanimate) objects. Animals (a lot of them wild birds) were sold by itinerant vendors, travellers or shops (and even later commercial menageries). Tague's exploration of pet-keeping makes use of various material, from children's stories, like Sarah Trimmer's Fabulous Histories: Designed for the Instruction of Children Respecting Their Treatment of Animals (1786), later published as The History of the Robins (a key text in the history of children's literature warning children and parents alike against over-indulgence in pets), to advertisements for lost dogs.

3 Chapter 2 focuses more on exotic beasts and examines how they became entangled in the debate on slavery and the issue of the morality of forms of enslavement. Tague relies here once again on children's literature (such as John Aikin's and Anna Lætitia Barbauld's Evenings at Home; or, the juvenile budget opened (1792-96) and Trimmer's Fabulous Histories) to probe the question of humans' rights to use animals, domesticate them and bring them under control. The rise of humanitarianism in the last decades of the eighteenth century meant that the question of the treatment and uses of animals, as well as the feelings of both humans and animals, came under scrutiny. The concept of sensibility, in particular, "with its emphasis on heightened emotion and compassion for the suffering of others" (68), informed debates around animals. Moreover, pets were not necessarily the main preoccupation of animal rights advocates. The question of lower-class people's abuse of animals was also important, and pet-keeping was sometimes regarded as being synonymous with the protection for the weakest. In the field of children's literature, for instance, Edward Augustus Kendall's The Sparrow (1798), related from the point of view of a sparrow, overtly aligned birds with workhouse prisoners or slaves. Other writers, such as Thomas Percival in A Father's Instructions; Consisting of Moral Tales, Fables, and Reflections Designed to Promote the Love of Virtue, a Taste for Knowledge, and an Early Acquaintance with the Works of Nature (1796) dealt with the experience of caged birds and explicitly condemned animals used for amusement. Others, such as Barbauld, compared pet-keeping with African enslavement. As Tague explains, many of the children's writers of the time were abolitionists, and they exploited the issue of sympathy and stressed the feelings of nonhuman beings so as to ensure the moral development of children. The discourse on pets, especially in the children's literature of the time was not monolithic, however. As suggested, because pet-keeping could to some extent ensure the protection of vulnerable creatures, it was also frequently aligned with "benevolent paternalism" (88), "mitigating [therefore] the evils of animal slavery" (88).

4 In Chapter 3, Tague deals with pets as consumer goods within the context of concerns about luxury and its effects on British society. She looks at satirical representations of women and pets, and explains how they served to map out fears related to female sexuality, in particular in representations of women and monkeys. Tague underlines as well how children's literature increasingly depicted boys torturing animals and girls rescuing them - a pattern also typically found throughout the following century. In Chapter 4, Tague tackles the link between pet-keeping and the debate on class relations. Just as children's literature used pets to deal with the issue of enslavement, many books for children used animals to shape ideal class relations and offer "an orderly world in which both human and animal inferiors were kept in their proper 
place" (146). The children's literature of the time is contrasted with contemporary satires, many of which mocked humans' devotion to animals and "lack of compassion for other human beings". The way in which pets and animal servitude at large were used to reinforce "the values of social order and paternalism" (152) could explain, as Tague surmises, the pervasive presence of animals in eighteenth-century literature for children. The second part of the chapter deals with the dog tax, which emerged in the 1730s and was passed in 1796, and its moral aspects (to combat concerns about the effects of luxury or prevent working-class abuse of animals, such as dogs). The debate around pet-keeping thus involved questions related to class just as pet-keeping could be seen as indicative of moral virtue.

In Chapter 5, Tague shows how the dual view of pets as both signs of sentiment and (potentially) of self-indulgence increased during the century. More and more women were portrayed with pets as illustrations of maternal care. Furthermore, the rise of the humane movement also contributed to changing the view of animals and their owners, the former often revealing the latter's humanity. Sensibility, as an aesthetic movement, played a crucial role as well in the transformation of views of pets, animals and humans' relationships with non-humans. Interestingly, Tague's study contrasts visual representations of children with pets, especially little girls generally represented in a very positive way (pets emphasizing their innate maternal qualities and shaping them as future mothers) and the children's literature of the time which, as seen in the previous chapters, invited children to experience sympathy and proposed the point of view of the animal. Studies of the personal writings of pet owners (Isabella Wentworth, William Cowper, Gilbert White and Horace Walpole) further the analysis whilst Tague shows how animals (both domestic and exotic) were used by naturalists alongside stuffed specimens, exhibitions or books to develop natural historical knowledge. The study of Horace Walpole's correspondence, in particular, Walpole being the best known eighteenth-century pet-owner, is illuminating. Tague recalls how animals inspired many of Walpole's writings. Walpole, known for his distrust of the human species (which he saw as "pestilently bad and malevolent" (qtd. 219)), believed the animal world abounded in sympathy. Walpole also frequently alluded to William Wentworth, Earl of Strafford, and his wife, Anne, whose menagerie in Yorkshire was often discussed in their correspondence.

6 Tague's book meticulously traces the birth of the modern pet in eighteenth-century Britain and painstakingly identifies contemporary concerns around the relationships between humans and non humans. She also clearly traces the changing views and definitions of pets throughout the century, and explains how pets helped inform wider debates on slavery and how their understanding and definition were in turn informed by the culture of sensibility or the humane movement. By focusing on the eighteenth century, Tague's study offers a brand new perspective for specialists of animal studies familiar with Kathleen Kete, Harriet Ritvo or Katherine Grier - all of them arguing that pet-keeping really became widespread a century later. The wealth of materials Tague brings together for her study, moreover, helps her draw a complex but thorough portrait of pet-keeping in the eighteenth-century whose intertextual approach will prove a compelling and stimulating addition to historical and literary studies on animals in the eighteenth-century. 
INDEX

Mots-clés : animaux de compagnie, Grande Bretagne, dix-huitième siècle

Keywords : animals, pet-keeping, Great Britain, eighteenth century

\section{AUTEURS}

\section{LAURENCE TALAIRACH-VIELMAS}

Professeur des Universités

Université de Toulouse - Jean Jaurès

laurence.talairach-vielmas@univ-tlse2.fr 